Annals of Warsaw University of Life Sciences - SGGW

Land Reclamation No 47 (3), 2015: 261-273

(Ann. Warsaw Univ. of Life Sci. - SGGW, Land Reclam. 47 (3), 2015)

\title{
Thermal growing season in Poland calculated by two different methods
}

\author{
MAŁGORZATA KĘPIŃSKA-KASPRZAK, PRZEMYSŁAW MAGER \\ Institute of Meteorology and Water Management - National Research Institute
}

\begin{abstract}
Thermal growing season in Poland calculated by two different methods. Methods of identifying dates of passing determined threshold value are of significant importance in the study of thermal growing seasons. The difficulty to determine dates of beginning and end of growing season in a given year stems from the fact that daily mean air temperature changes irregularly on a day-to-day basis often crossing the threshold value (i.e. $5^{\circ} \mathrm{C}$ ) multiple times. The most frequently used method to identify dates of threshold value crossing is the mathematical or graphical method proposed by Gumiński in 1950 which based on monthly mean air temperature values. In the 1970s, Huculak and Makowiec presented a method using daily mean values of air temperature. It is assumed that both methods give comparative results although calculations of daily mean air temperature render more accurate results. This paper presents the comparison of these two methods. Air temperatures measurements from 1966-2005 taken at 38 weather stations located in various physiographic conditions in Poland were used.
\end{abstract}

Key words: thermal growing season, Gumiński method, Huculak and Makowiec method, Poland

\section{INTRODUCTION}

Determination of long-term changes of beginning and end dates of growing season is of importance mainly in climatology and agrometeorology. In case of agriculture, particularly, the knowledge of these dates is of practical value - it allows to select the optimal type of crops, determinate of future crop plant growth and development conditions, and consequently, to project crop yields. Changes of beginning and end dates of growing season as well as its duration are also one of the climate change indices.

Growing period in Poland is closely related to dates of permanent crossing the $+5^{\circ} \mathrm{C}$ daily mean air temperature threshold value. Because the ecological factor affecting the rate of plant life processes is thermal conditions, the duration of growing period is approximately equal to thermal growing season (TGS). Regardless of whether a year is divided into six or more thermal seasons, the same threshold value of air temperature initiates thermal "spring". A permanent decrease of daily mean air temperature below $5^{\circ}$, on the other hand, terminates both growing season and thermal season - "fall". Hence, discussion related to determination of growing season duration and thermal seasons concerns in fact one and the same problem that can be found in works on both growing period and thermal seasons.

The basic methodological problem in regards determination of thermal seasons and hence growing period is the multiple threshold crossing by air temperature. This is due to the fact that, in the Central European climate conditions, changes of this meteorological param- 
eter are not uniform but, most of the time, irregular - after a few days of increase, air temperature values fall again. This phenomenon was discussed by, among others, Huculak and Makowiec (1977), Rozkosz (1986), Nowosad and Filipiuk (1998), Żmudzka (2001), and Piotrowicz (2002). For this reason, finding a method that would successfully solve this problem poses significant difficulty. Over the last decades, there were several attempts to find methodological solutions some of which are presented in Table 1.

Table 1 shows that the most common method to determine dates of threshold crossing is the analysis of monthly or daily mean values. The problem of multiple threshold crossing is not as pertinent if monthly mean temperatures are used as input data (which is understandable because such data provide per se averaged air temperature value for a given month) as it is if daily mean temperature values are used. Also, multiple threshold crossing is not an issue in case of multiannual mean dates, especially since the longer the period for which monthly or daily mean temperatures were calculated as "input" data, the lesser the number of threshold crossing occurrences. Nonetheless, as it was noted by Piotrowicz (2002), even when she used daily air temperatures for 170-year period (1826$-1995)$ for determining winter beginning dates, she observed a situation where $0^{\circ} \mathrm{C}$ threshold was crossed three times in the first decade of December.

Determination of dates of temperature threshold crossing in respective years, therefore, poses the biggest difficulty due to high probability of such occurrence. Czernecki and Miętus (2010), among others, point out that in such cases the method used to determine the sought date is of key importance and significantly affects the result.

This paper presents the differences in results between two methods for determination of dates of temperature threshold crossings: Gumiński method based on monthly mean temperatures and the method proposed by Huculak and Makowiec based on daily mean temperatures.

\section{MATERIAL AND METHODS}

In this paper, daily mean air temperatures from 38 meteorological stations of the Institute of Meteorology and Water Management - National Research Institute located in different parts of Poland were used. Distribution of the stations is relatively regular and their localizations represent various physico-geographic and climate regions of Poland. The study is based on data series from multiyear period of 1966-2005.

Two most frequently used in Poland methods for determination of beginning and end of thermal growing season (TGS) were selected for the analysis: R. Gumiński method and W. Huculak and M. Makowiec method.

Gumiński method (Gumiński 1950) is based on the assumption that each month is 30 days long and intermonthly temperature change is linear:

$x=30\left[\left(5^{\circ}-t_{1}\right) /\left(t_{2}-t_{1}\right)\right]$

and $x=30\left[\left(t_{1}-5^{\circ}\right) /\left(t_{1}-t_{2}\right)\right]$

where:

$t_{1}$ - mean air temperature of the month preceding temperature threshold value; $t_{2}$ - mean air temperature of the month following threshold value. 
TABLE 1. Examples of methodological solutions for thermal season determination in Poland

\begin{tabular}{|c|c|c|c|}
\hline $\begin{array}{l}\text { Basis for ther- } \\
\text { mal threshold } \\
\text { determination }\end{array}$ & Method & $\begin{array}{l}\text { Period for } \\
\text { which the } \\
\text { method is } \\
\text { used }\end{array}$ & $\begin{array}{l}\text { Examples of works using the given } \\
\text { method }\end{array}$ \\
\hline \multirow{3}{*}{$\begin{array}{l}\text { Monthly } \\
\text { mean air } \\
\text { temperature }\end{array}$} & \multirow[t]{2}{*}{ mathematical method } & $\begin{array}{l}\text { multiannual } \\
\text { period }\end{array}$ & $\begin{array}{l}\text { Gumiński (1950), Nowosad and } \\
\text { Filipiuk (1998), Kossowska-Cezak et } \\
\text { al. (2000), Żmudzka (2001), Żmudzka } \\
\text { and Dobrowolska (2001), Piotrowicz } \\
\text { (2002), Climate Atlas of Poland (2005), } \\
\text { Bartoszek et al. (2012) }\end{array}$ \\
\hline & & $\begin{array}{l}\text { for respective } \\
\text { years }\end{array}$ & $\begin{array}{l}\text { Olszewski and Żmudzka (1997), } \\
\text { Piotrowicz (2002), Kossowska-Cezak } \\
\text { (2005), Czernecki and Miętus (2010), } \\
\text { Bartoszek et al. (2012) }\end{array}$ \\
\hline & $\begin{array}{l}\text { identification of date on } \\
\text { a chart at the crossing } \\
\text { point of a line connecting } \\
\text { monthly mean air tempera- } \\
\text { ture values and the value } \\
\text { of thermal threshold }\end{array}$ & $\begin{array}{l}\text { multiannual } \\
\text { period }\end{array}$ & $\begin{array}{l}\text { Wiszniewski (1960), Warszawski } \\
\text { (1971), Limanówka (1985), Niedź- } \\
\text { wiedź and Limanówka (1992), Piotro- } \\
\text { wicz (2002), Climate Atlas of Poland } \\
\text { (2005) }\end{array}$ \\
\hline \multirow{2}{*}{$\begin{array}{l}\text { Decadal mean } \\
\text { air } \\
\text { temperature }\end{array}$} & \multirow{2}{*}{$\begin{array}{l}\text { identification of date on } \\
\text { a chart at the crossing } \\
\text { point of a line connecting } \\
\text { decadal mean air tempera- } \\
\text { ture values and the value } \\
\text { of thermal threshold }\end{array}$} & $\begin{array}{l}\text { multiannual } \\
\text { period }\end{array}$ & Olszewski and Jarząb (1996) \\
\hline & & $\begin{array}{l}\text { for respective } \\
\text { years }\end{array}$ & Woś (2006) \\
\hline \multirow{5}{*}{$\begin{array}{l}\text { Daily mean } \\
\text { air } \\
\text { temperature }\end{array}$} & $\begin{array}{l}\text { dominance of days typical } \\
\text { for a given thermal season }\end{array}$ & \begin{tabular}{|l} 
for respective \\
years
\end{tabular} & Kosiba (1956), Mitosek 1961 \\
\hline & $\begin{array}{l}\text { daily mean value crosses } \\
\text { the thermal threshold }\end{array}$ & $\begin{array}{l}\text { multiannual } \\
\text { period }\end{array}$ & $\begin{array}{l}\text { Ustrnul (1986), Nowosad and Filipiuk } \\
\text { (1998), Kossowska-Cezak et al. (2000), } \\
\text { Piotrowicz (2002), Bartoszek et al. } \\
(2012)\end{array}$ \\
\hline & $\begin{array}{l}\text { cumulated deviation of } \\
\text { daily mean values from } \\
\text { respective threshold values }\end{array}$ & $\begin{array}{l}\text { for respective } \\
\text { years }\end{array}$ & $\begin{array}{l}\text { Huculak and Makowiec (1977), Ma- } \\
\text { kowiec (1983), Nowosad and Filipiuk } \\
\text { (1998), Żmudzka i Dobrowolska } \\
\text { (2001), Wegrzyn (2008), Czernecki } \\
\text { and Miętus (2010), Mager and Kopeć } \\
\text { (2010), Bartoszek and Węgrzyn (2011), } \\
\text { Bartoszek et al. (2012) }\end{array}$ \\
\hline & $\begin{array}{l}\text { the first or the last day in at } \\
\text { least } 3 \text {-day sequence }+ \text { ma- } \\
\text { jority of days are included } \\
\text { in a given season }\end{array}$ & $\begin{array}{l}\text { for respective } \\
\text { years }\end{array}$ & Rozkosz (1986), Piotrowicz (2002) \\
\hline & $\begin{array}{l}\text { daily mean value crosses } \\
\text { given threshold }+ \text { analysis } \\
\text { of the mean value of } \\
\text { a period in question }\end{array}$ & $\begin{array}{l}\text { for respective } \\
\text { years }\end{array}$ & Łepko et al. (2011) \\
\hline
\end{tabular}


Using both equations enables to calculate the number of days which after adding to the $15^{\text {th }}$ day of the month prior to threshold temperature indicates the date of beginning or end, respectively, of thermal growing season.

The Huculak-Makowiec method (1977), on the other hand, determines beginning and end dates of TGS based on the following assumptions:

- the beginning of TGS in a given year is the earliest date of a series of days with the mean daily air temperature $\geq 5^{\circ} \mathrm{C}$ that is the beginning of such cumulated series of daily mean temperature deviations from the threshold value of $5^{\circ} \mathrm{C}$ that do not have negative values up to the end of the first 6 months of a year;

- the end of TGS in a given year is a day directly preceding the earliest date after the beginning of TGS of a series of days with the mean daily air temperature $\leq 5^{\circ} \mathrm{C}$ that is the beginning of such cumulated series of daily mean temperature deviations from the threshold value of $5^{\circ} \mathrm{C}$ that do not have positive values up to the end of the end of a year.

The key difference between these two methods is the use of different input data - monthly mean values of air temperature in the Gumiński method and daily means in the Huculak-Makowiec method. Because of a better access to monthly mean temperatures, the Gumiński method had wider application despite many objections that TGS determination based on daily data gives much more accurate results.

In order to indicate the possible differences in onset and offset dates of TGS determined by the two methods, those dates were calculated for each year of the 1966-2005 period and for each of the 38 stations using both methods. Next, the differences between the dates (expressed in the number of days) of TGS beginning $\left(\mathrm{P}_{\mathrm{H}-\mathrm{M}}-\mathrm{P}_{\mathrm{G}}\right)$ and end $\left(\mathrm{K}_{\mathrm{H}-\mathrm{M}}-\mathrm{K}_{\mathrm{G}}\right)$ derived from the Huculak-Makowiec and Gumiński methods were calculated for respective years and stations. The resulting differences were analyzed for frequency of occurrences in the following classes adopted by the authors: 0 days, $1-3,4-9,10-15,16$ and more days. Spatial distribution of the maximum deviations and statistically significant differences between multiannual mean dates derived from both methods for each station are presented.

\section{RESULTS AND DISCUSSION}

Tables 2 and 3 illustrate the magnitude of differences (in number of days) between the TGS beginning and end dates in respective years of the 1966-2005 period calculated using both analyzed methods. The stations in the tables are grouped by regions, taking into account several different magnitudes between TGS beginning and end dates, which are calculated by using both methods. Data presented in the tables show that several possibilities exist:

- single years in which the differences were of different signs but did not exceed 9 days (e.g. TGS beginning in 1994, TGS end in 1988 and 1995) in the entire area of Poland;

- differences only in the same sign (e.g. only positive - TGS beginning in 1995 and 1996 or only negative - TGS end in 1987 and 1991) in a given year; 
TABLE 2. Differences (number of days) between TGS beginning dates calculated using Huculak-Makowiec and Gumiński methods $\left(\mathrm{P}_{\mathrm{H}-\mathrm{M}}-\mathrm{P}_{\mathrm{G}}\right)$

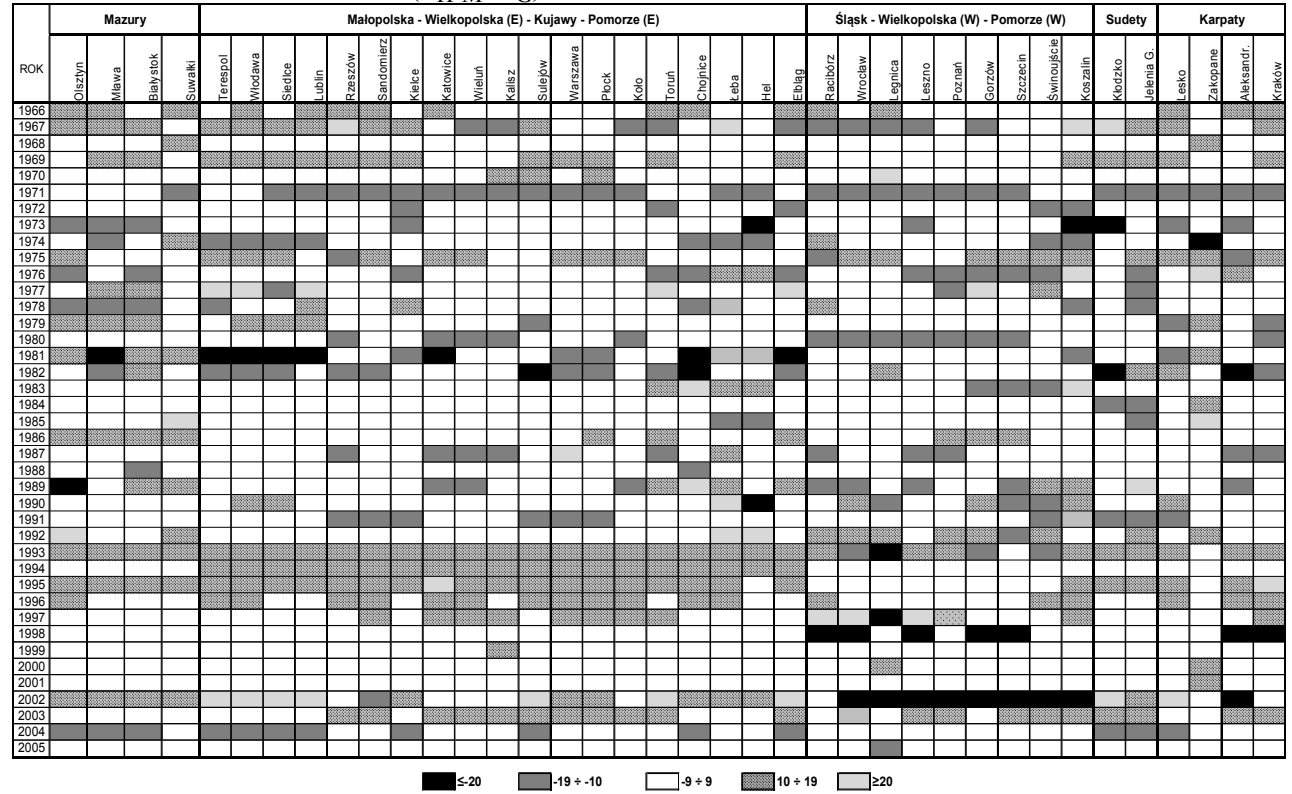

TABLE 3. Differences (number of days) between TGS end dates calculated using Huculak-Makowiec and Gumiński methods $\left(\mathrm{K}_{\mathrm{H}-\mathrm{M}}-\mathrm{K}_{\mathrm{G}}\right)$

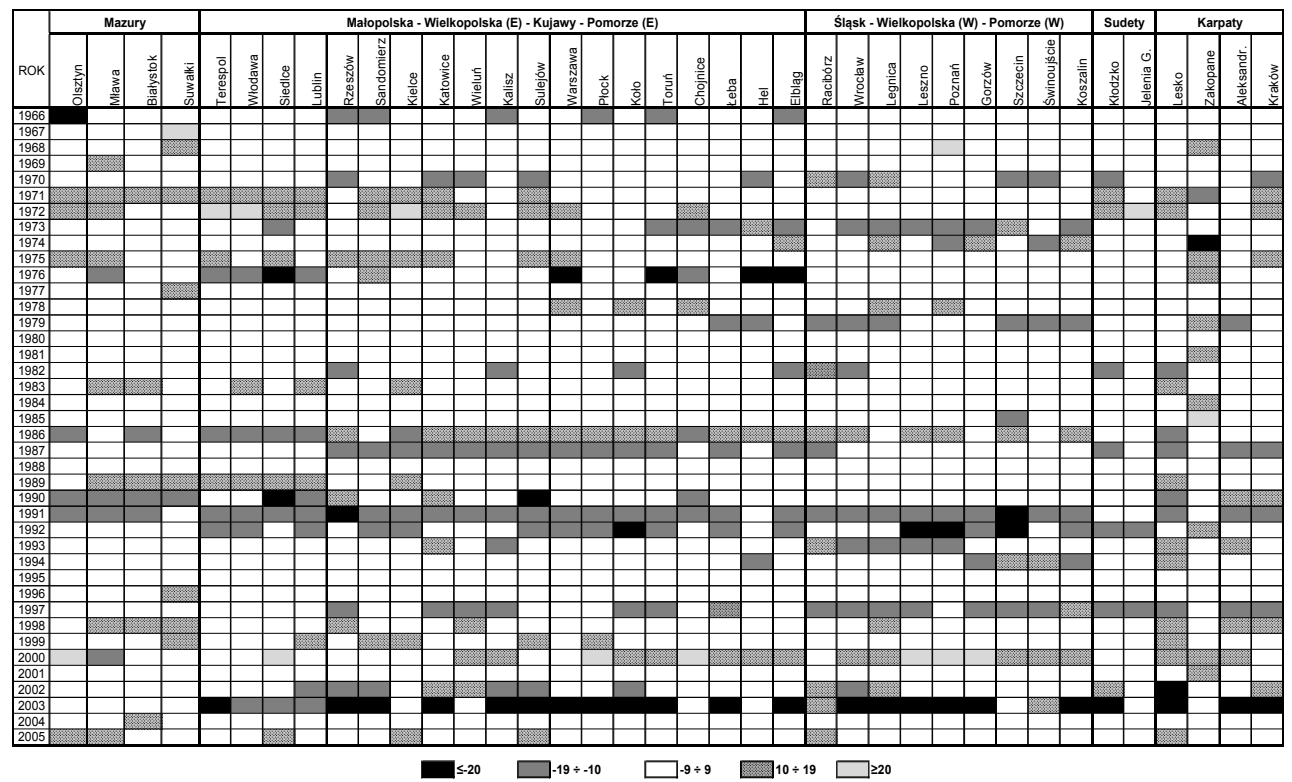


- in a given year, differences in opposite signs with values higher than 19 days (e.g. TGS beginning in 2002).

The analysis of TGS onset dates calculated using Gumiński and Huculak-Makowiec methods for respective years and stations showed that about $25 \%$ of all differences were no higher than 3 days (Fig. 1). Differences lower than a decade (9 days and less) constituted only $60 \%$ of the total and as many as $30 \%$ were differences of 10-15 days. However, it is impossible to explicitly state which of the two methods indicates earlier or later TGS beginning date because almost the number of positive and negative differences was almost the same for each station.

Similar results were received in difference magnitude between the two methods in regard to TGS end dates (Fig. 2 ). Small differences ( $0-3$ days) between the methods were noted in $30 \%$ of total cases, differences smaller than decade (0-9 days) - almost $70 \%$. In less than $20 \%$ of all cases, the differences were $10-15$ days and they were higher in only few cases (7\%). As is the case with TGS onset date, it is impossible to determine which of the two methods indicates earlier or later TGS offset (almost the same number of positive and negative differences).

Although total percentile of $\mathrm{P}_{\mathrm{H}-\mathrm{M}}-\mathrm{P}_{\mathrm{G}}$ positive deviations was almost equal to negative deviations, there were considerable differences in their extreme values. The maximum positive differences were slightly above 30 days (i.e. TGS beginning date derived from Gumiński method was maximally over 30 days earlier than date derived from Huculak-Makowiec method). The highest negative differences, on the other hand, were as high as over 70 days (i.e. Gumiński method indicated over 70 days delay of TGS beginning date).

Frequency distribution of maximum positive differences in TGS beginning dates derived from both methods (i.e. TGS beginning date using Gumiński method was earlier than the date indicated by Huculak-Makowiec method) is presented in Figure 3. The maximum positive deviations were 20-30 days for almost the entire country with the exception of few stations (located mostly in central Poland) where they were smaller than 20 days. The positive deviations

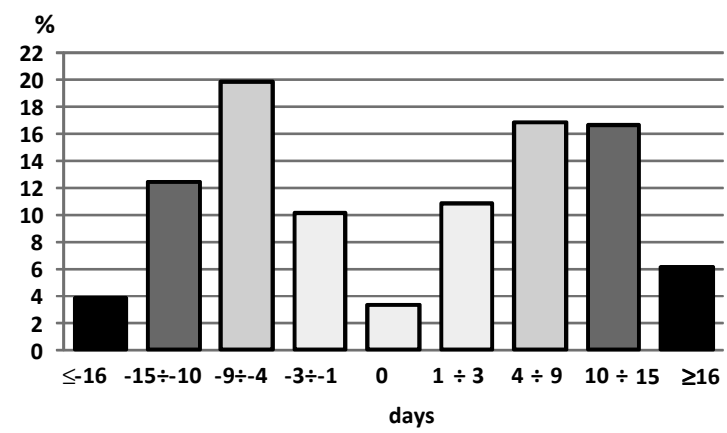

FIGURE 1. Frequency distribution of differences (number of days) between TGS beginning dates calculated using Huculak-Makowiec and Gumiński methods $\left(\mathrm{P}_{\mathrm{H}-\mathrm{M}}-\mathrm{P}_{\mathrm{G}}\right)$ 


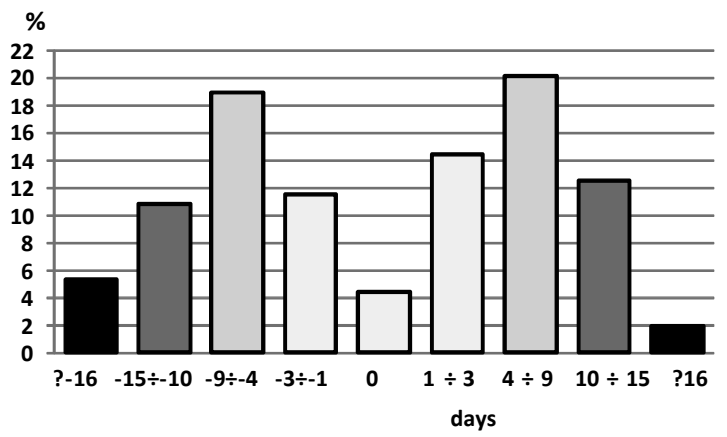

FIGURE 2. Frequency distribution of differences (number of days) between TGS end dates calculated using Huculak-Makowiec and Gumiński methods $\left(\mathrm{K}_{\mathrm{H}-\mathrm{M}}-\mathrm{K}_{\mathrm{G}}\right)$

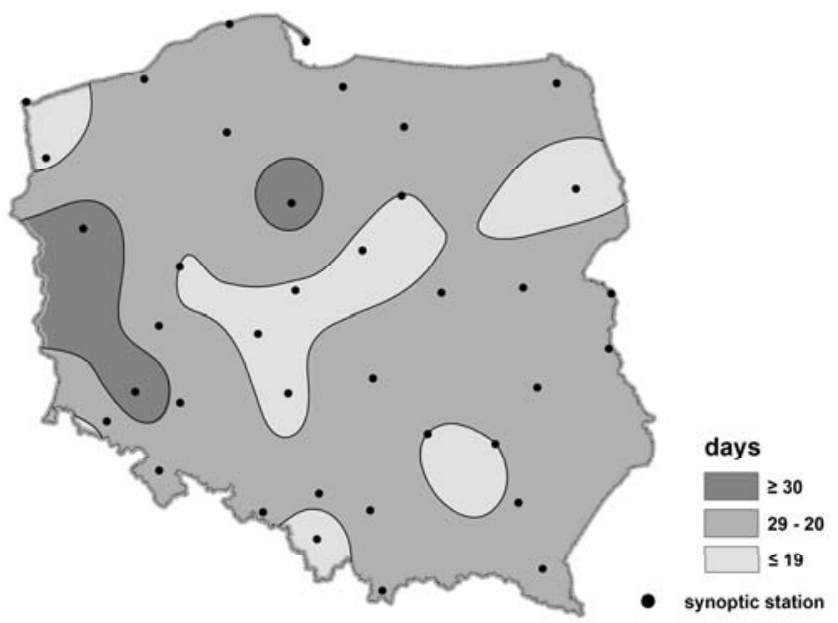

FIGURE 3. TGS beginning date - maximum positive differences between dates derived from Huculak-Makowiec and Gumiński methods $\left(\mathrm{P}_{\mathrm{H}-\mathrm{M}}-\mathrm{P}_{\mathrm{G}}\right)$

over one month were noted for only three stations during the entire analyzed period.

Frequency distribution of maximum negative differences (i.e. TGS beginning dates calculated using Gumiński method were later than those derived from Huculak-Makowiec method) has a visible longitudinal orientation (Fig. 4). Differences of up to 40-70 days were mostly observed for stations located in western Poland and the smallest differences in the belt extending from eastern part of coast through central Poland to south west, and in north-eastern Poland.

In case of TGS end dates, the maximum differences between the analyzed methods were not as high as TGS beginning dates. The maximum positive differences (i.e. TGS offset calculated with Gumiński method was earlier than the one derived using Huculak-Makowiec method) were not much higher than 30 days (Fig. 5) and were found mostly 


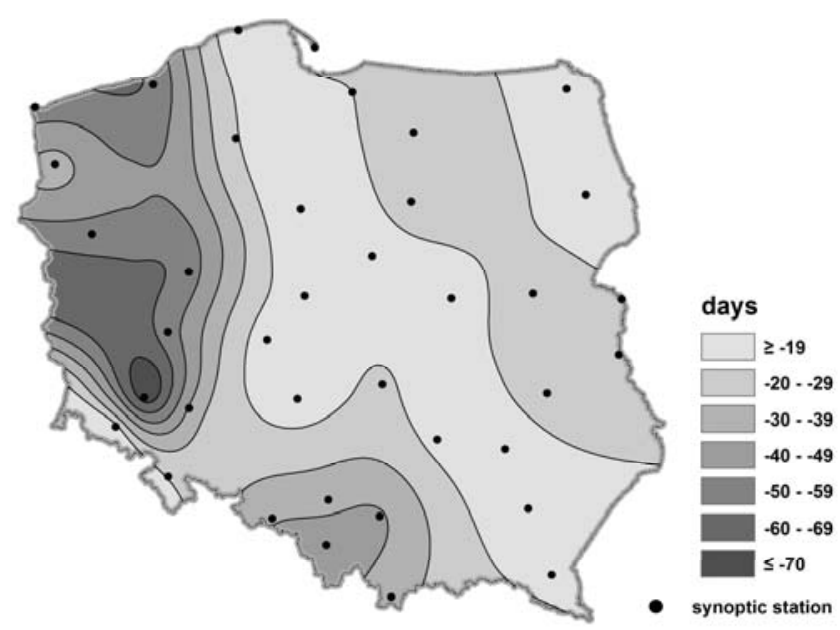

FIGURE 4. TGS beginning date - maximum negative differences between dates derived from Huculak-Makowiec and Gumiński methods $\left(\mathrm{P}_{\mathrm{H}-\mathrm{M}}-\mathrm{P}_{\mathrm{G}}\right)$

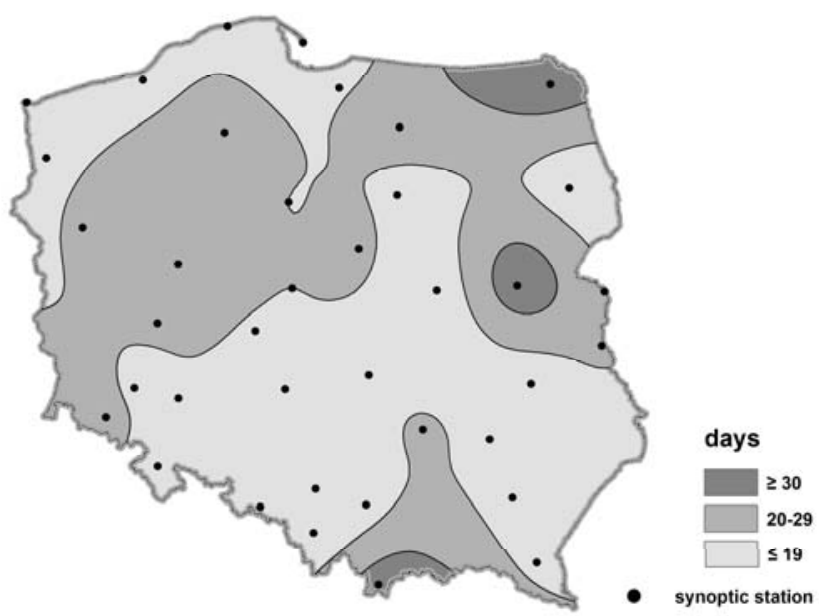

FIGURE 5. TGS end date - maximum positive differences between dates derived from Huculak-Makowiec and Gumiński methods $\left(\mathrm{K}_{\mathrm{H}-\mathrm{M}}-\mathrm{K}_{\mathrm{G}}\right)$

in central and south Poland, and a few cases along the Baltic Sea coast.

A little higher span of differences was noted for negative differences (i.e. TGS end dates calculated using Gumiński method were later than those derived from Huculak-Makowiec method). The differences between the two methods reaching over 40 days were noted in western and south-eastern Poland as well as some locations in central and south Poland while the smallest differences (up to 19 days) in eastern Poland (Fig. 6).

So far the differences in TGS beginning and end days derived from Gumiński and Huculak-Makowiec methods were 


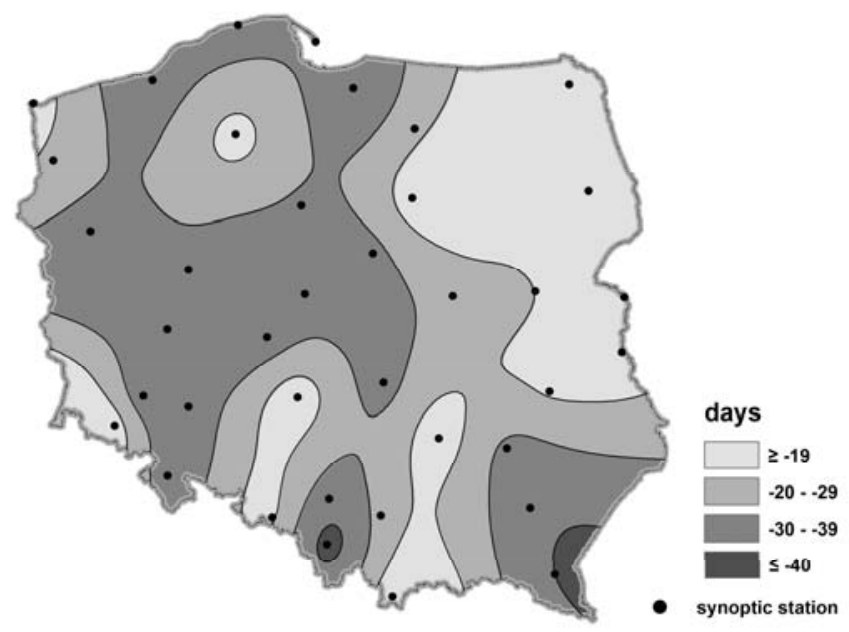

FIGURE 6. TGS end date - maximum negative differences between dates derived from Huculak-Makowiec and Gumiński methods $\left(\mathrm{K}_{\mathrm{H}-\mathrm{M}}-\mathrm{K}_{\mathrm{G}}\right)$

described in this paper. However, the magnitude of these differences does not provide the information whether they are statistically significant. To find the answer, statistical significance of differences between multiannual mean dates received from both methods were analyzed for each station. Parametric test based on $u$-statistic with normal distribution, $\mathrm{N}(0,1)$, was used:

$$
u=\frac{\overline{x_{1}}-\overline{x_{2}}}{\sqrt{\frac{s_{1}{ }^{2}}{n_{1}}+\frac{s_{2}{ }^{2}}{n_{2}}}}
$$

where:

$x_{1}, x_{2}$ - mean values from samples; $n_{1}, n_{2}$ - number of samples;

$s_{1}, s_{2}-$ standard deviation.

The test showed that at the adopted significance level of $\alpha=0.05$, no basis exists to reject the hypothesis that multiannual mean TGS beginning and end dates derived from the two used meth- ods are the same. The only exception was Suwałki station where statistically significant difference was identified between the multiyear mean date of TGS onset derived from both analyzed methods. This finding leads to conclusion that Gumiński and Huculak-Makowiec methods used for determination of multiannual mean dates of TGS beginning and end rendered very similar results.

Many other authors who carried out similar analyses came to analogous conclusions although based on smaller statistic material. Huculak and Makowiec (1977) analyzed TGS beginning and end dates calculated on the basis of air temperature measurements taken at Rogowiec station in 1951-1970 derived from three different methods: multiannual monthly mean values temperature, multiannual daily mean temperatures and their own method. After calculating the values for each respective year, they concluded that the differences in results using each of the three methods are small. Żmudzka 
and Dobrowolska (2001) who used in their work Gumiński and Huculak-Makowiec methods came to the conclusion that the results were slightly different but those differences were statistically insignificant. Żmudzka (2001) concluded that the results based on daily mean temperature values were to some extent more accurate than the results based on monthly values but, nonetheless, differences were small and indicate the both methods are reliable and useful. Also Bartoszek et al. (2012) after the analysis of data for the 1976-2010 period from five stations located in Lubelskie Voivodship concluded that for determination of multiannual mean date of TGS onset and offset in the analyzed area the methods of Huculak-Makowiec and Gumiński are interchangeable and equally useful. They showed insignificant differences between dates derived from both methods. At the same time, analyses carried out by Bartoszek et al. (2012) indicated that the Gumiński method should be avoided in determination of TGS beginning and end dates. This problem was also discussed by Czernecki and Miętus (2010) who wrote that using equations proposed by Gumiński requires additional meteorological assumptions regarding multiple threshold crossing from "below" and "above" in respective months. K. Piotrowicz (2002) arrived to similar conclusion based on values of air temperatures in Cracow in 170-year period (1826-1995) as she noticed that monthly mean air temperature values were useful only for determination of multiannual averages. Kossowska-Cezak (2005), on the other hand wrote: "Gumiński method was proposed for multiannual mean values of temperature. To use it for single year, when daily mean temperature can cross the adapted threshold value separating seasons even multiple times, is a sort of 'abuse' of this method". Nonetheless, Kossowska-Cezak used this method to determine TGS dates in respective years and, quoting Marsz and Żmudzka (2002) and Żmudzka et al. (2003), she stated that "the method gives results comparable to results derived from other methods based on daily temperature values". However, the analyses presented in this article show that this opinion is unsubstantiated. It was shown that in case of TGS onset and offset dates determined for the respective years of 19662005 period as much as about $73 \%$ of results derived from Gumiński method were different by more than 3 days than dates calculated using Huculak-Makowiec method, and in $35 \%$ of cases even by more than 9 days.

\section{CONCLUSIONS}

The article presented the analysis of dates of threshold crossing by air temperature derived from Gumiński method (based on monthly mean values) and from Huculak-Makowiec method (based on daily mean temperatures). The analysis was based on exceptionally large observation material consisting of daily mean air temperatures from 1966-2005 period from 38 synoptic stations from the entire area of Poland. The results showed that there were significant differences of TGS beginning and end dates in respective years which in case of TGS onset were as high as over 70 days and TGS offset - over 40 days. However, it is impossible to state conclusively which 
of the two methods indicates earlier of later beginning or end of TGS because, in total, the similar number of negative and positive differences.

Despite considerable discrepancies in respective years of the entire 40-year period, the analysis showed that there were no statistically significant $(\alpha=0.05)$ differences between multiannual mean TGS beginning and end dates derived from the examined methods. It can, therefore, be concluded that Gumiński and HuculakMakowiec methods for determination of multiannual mean TGS dates of beginning and end give very similar results.

Many authors analyzing TGS points out that onset and offset dates of TGS based on daily mean temperatures should be considered as more accurate than those determined on the basis of monthly mean temperatures. In our opinion, comparison of the received results to results of phenological observation from respective years and/or vegetation indices from remote sensing could be very useful. Results of such comparisons would be a valuable indication as to the usefulness of each method.

\section{REFERENCES}

Atlas Klimatu Polski (Climate Atlas of Poland) 2005. H. Lorenc (Ed.) IMGW, Warszawa.

BARTOSZEK K., WĘGRZYN A. 2011: Uwarunkowania cyrkulacyjne początku okresu wegetacyjnego w Polsce Wschodniej (The circulation conditions of the vegetation season beginning in eastern Poland). Annales Universitatis Mariae Curie-Skłodowska Lublin - Polonia, B, 1, 93-102 [Engl. summ.].

BARTOSZEK K., WĘGRZYN A., KASZEWSKI B. M., SIŁUCH M. 2012:
Porównanie wybranych metod wyznaczania dat początku i końca okresu wegetacyjnego na przykładzie Lubelszczyzny (Comparison of selecteds methods for determining onset and offset the growing season on the example of the Lublin region). Przeglad Geofizyczny 57 (1), 123 -134 [Engl. summ.].

CZERNECKI B., MIĘTUS M. 2010: Wstępna analiza występowania i zmienności termicznych pór roku w wybranych regionach Polski na przykładzie Pasa Pobrzeży Południowobałtyckich i Wyżyn Polskich (Initial analyse of the thermal seasons occurance and variability in chosen regions of Poland. Study case of the Polish Baltic Coast and the Polish Highlands). In: E. Bednorz (Eds). Klimat Polski na tle klimatu Europy. Warunki termiczne i opadowe. Studia i Prace z Geografii $i$ Geologii 15, 9-26 [Engl. summ.].

GUMIŃSKI R. 1950: Ważniejsze elementy klimatu rolniczego Polski południowowschodniej (Important aspects of agricultural climate in south-east Poland). Wiadomości Stużby Hydrologicznej i Meteorologicznej 3 (1), 57-113.

HUCULAK W., MAKOWIEC M. 1977: Wyznaczanie meteorologicznego okresu wegetacyjnego na podstawie jednorocznych materiałów obserwacyjnych (Determination of meteorological growing season based on 12-month observation material). Zeszyty Naukowe $S G G W A R$, Leśnictwo 25, 65-74.

KOSIBA A. 1956: Zagadnienie klasyfikacji zim (Problem of classification of winters). Przeglad Geofizyczny 1 (9), 201-208.

KOSSOWSKA-CEZAK U. 2005: Zmiany termicznych pór roku w Warszawie w okresie 1933-2004 (Changes of the thermic seasons in Warsaw). Przeglad Geofizyczny 50 (3-4), 265-277 [Engl. summ.].

KOSSOWSKA-CEZAK U., MARTYN D., OLSZEWSKI K., KOPACZ-LEMBOWICZ M. 2000: Meteorologia i klimatologia. PWN, Warszawa-Łódź. 
LIMANÓWKA D. 1985: Okres wegetacyjny w Polskich Karpatach Zachodnich (Thermal growing season in the Polish Western Carpathians Mts.). Folia Geographica, Geographica-Physica 17, 63-78 [Engl. summ.].

ŁEPKO M., KOZAK J., JURKIEWICZ T. 2011: Zmienność termicznych pór roku w masywie Trzech Koron w Pieninach (Variability of thermal seasons in the Trzy Korony range in the Pieniny Mts.). Nauka Przyroda Technologie, Melioracje $i$ Inżynieria Środowiska 4, 1-9 [Engl. summ.].

MAGER P., KOPEĆ M. 2010: Okres wegetacyjny w Polsce i w Europie w dobie obserwowanego ocieplenia (Growing season in Poland and Europe in the context of contemporary warming). In: E. Bednorz, L. Kolendowicz (Eds). Klimat Polski na tle klimatu Europy. Zmiany i ich konsekwencje. Studia i Prace z Geografil $i$ Geologii 16, 49-63 [Engl. summ.].

MAKOWIEC M. 1983: Wyznaczanie termicznych pór roku (Calculation of the thermic seasons of year). Przeglad Geofizyczny 28 (2), 209-220 [Engl. summ.].

MARSZ A.A., ŻMUDZKA E. 2002: Zwiazki początku termicznego okresu wegetacyjnego w Polsce $\mathrm{z}$ anomaliami temperatury powierzchni wody na Atlantyku Północnym - problem prognozy długoterminowej (The realation of the beginning of the thermal growing season in Poland and anomalies in the sea surface temperature on the Northern Atlantic - problem of long-term forecast). Przeglad Geofizyczny 47 (3-4), 165-202 [Engl. summ.].

MITOSEK H. 1961: Próba klasyfikacji termicznej zim na podstawie spostrzeżeń meteorologicznych w Puławach w latach 1918-1960 (Thermal classification of winters based on meteorological observations in Puławy for the period of 1918-1960]. Pamiętnik Puławski, Prace IUNG 3, 207-246.

NIEDŹWIEDŹ T., LIMANÓWKA D. 1992: Termiczne pory roku w Polsce (Thermal seasons in Poland). Zeszyty Naukowe
Uniwersytetu Jagiellońskiego. Prace Geograficzne 90, 53-69 [Engl. summ.].

NOWOSAD M., FILIPIUK E. 1998: Zmiany czasu trwania termicznych pór roku w Lublinie w latach 1951-1995 (The changes of the duration of the thermal seasons at Lublin in the period 1951-1995). Acta Universitatis Lodziensis, Folia Geographica Physica 3, 231-240 [Engl. summ.].

OLSZEWSKI J.L., JARZAZB B. 1996: Termiczne pory roku w środkowej części Gór Świętokrzyskich (Thermal seasons in the central part of the Swiętokrzyskie Mountains). Rocznik Świętokrzyski, B - Nauki Przyrodnicze 23, 91-108 [Engl. summ.].

OLSZEWSKI K., ŻMUDZKA E. 1997: Zmiany okresu wegetacyjnego w Polsce (Changes of length of the vegetative period in Poland). Prace $i$ Studia Geograficzne 20, 93-103 [Engl. summ.].

PIOTROWICZ K. 2002: Metody wyznaczania dat początku i końca termicznych zim na przykładzie krakowskiej serii pomiarów temperatury powietrza (Methods for the determination of the thermal winter beginning and end dates, based on the Crakow air temperature records). Przeglad Geofizyczny 47 (1-2), 81-92 [Engl. summ.].

ROZKOSZ G. 1986: Termiczne pory roku w Katowicach w okresie 1961-1980 (Thermal seasons of the year in Katowice in the period 1961-1980). Wiadomości IMGW 9 (2), 31-38 [Engl. summ.].

USTRNUL Z. 1986: Okresy termiczne w Karkonoszach (Thermal periods in the Karkonosze Range). Wiadomości IMGW 9 (4), 91-100 [Engl. sum.].

WARSZAWSKI W. 1971: Termiczne pory roku w Polsce (Thermic seasons in Poland). Zeszyty Naukowe Uniwersytetu Łódzkiego, Nauki Matematyczno-Przyrodnicze, II 43, 105-137 [Engl. summ.].

WEGRZYN A. 2008: Typowe i anomalne długości okresu wegetacyjnego na Lubelszczyźnie (Typical and anomalous duration of growing seasons in Lubelskie 
Voivodship). Acta Agrophysica 12 (2), 561-573 [Engl. summ.].

WISZNIEWSKI W. 1960: Kilka uwag o meteorologicznych porach roku w Polsce w świetle wieloletnich wartości temperatur (Some remarks concerning meteorological seasons of the year in Poland from the point of view of the normal temperatures). Przeglad Geofizyczny 5 (1), 31-39.

WOŚ A. 2006: Termiczne pory roku w Poznaniu w drugiej połowie XX wieku (Thermal seasons in Poznan in the second half of the 20th century). In: J. Trepińska, Z. Olecki (Eds). Klimatyczne aspekty środowiska geograficznego, 117-125 [Engl. summ.].

ŻMUDZKA E. 2001: Termiczny okres wegetacyjny w Polsce (Thermal growing season in Poland). Geografia w Szkole 4, 206-214.

ŻMUDZKA E., DOBROWOLSKA M. 2001: Zmienność termicznego okresu wegetacyjnego w Polsce w drugiej połowie XX wieku (Variability of thermal growing season in Poland in the second half of the 20th century). Prace $i$ Studia Geograficzne 29, 127-136 [Engl. summ.].

ŻMUDZKA E., KOSSOWSKA-CEZAK U., DOBROWOLSKA M. 2003: Circulation requirement of the urban heat island variations in Warsaw. Proceeding of International Conference of Urban Climate, 1-5.09.2003, Łódź.
Streszczenie: Termiczny okres wegetacyjny $w$ Polsce wyznaczony dwoma różnymi metodami. Okres wegetacyjny, będący okresem aktywności życiowej roślin, jest jednym z najważniejszych okresów rolniczych określających warunki funkcjonowania rolnictwa. Na podstawie obserwacji fenologicznych przyjmuje się, że okres wegetacji większości roślin w Polsce odpowiada porze roku, podczas której średnia dobowa temperatura powietrza wynosi co najmniej $5^{\circ} \mathrm{C}$. Tak wyznaczony okres bywa najczęściej nazywamy termicznym okresem wegetacyjnym (TGS). $\mathrm{W}$ pracy przedstawiono różnice $\mathrm{w}$ datach przejścia temperatury powietrza przez wartość progową $5^{\circ} \mathrm{C}$ za pomocą dwóch najczęściej stosowanych do tego celu w Polsce metod: Gumińskiego (opartej na średnich miesięcznych wartościach temperatury) oraz Huculaka i Makowca (opartej na średnich dobowych wartościach temperatury). Stosując metodę Gumińskiego, zastosowano zaproponowany przez tego autora wzór matematyczny. Jako materiał do analiz wykorzystano pomiary temperatury powietrza prowadzone w latach 1966-2005 na 38 stacjach synoptycznych położonych w różnych warunkach fizjograficznych na terenie Polski.

Stowa kluczowe: termiczny okres wegetacyjny, metoda Gumińskiego, metoda Huculaka i Makowca, Polska

\section{Authors' address:}

Małgorzata Kępińska-Kasprzak, Przemysław

Mager

Instytut Meteorologii i Gospodarki Wodnej

- Państwowy Instytut Badawczy

ul. Dąbrowskiego 174/176

60-594 Poznań, Poland

e-mail: Malgorzata.Kepinska-Kasprzak@imgw.pl Przemyslaw.Mager@imgw.pl 